\title{
Iulia Rădac
}

\section{The Stance of the Uriter \\ in a Teennger's Book: Mircen Glinde's Romanul Adolescentului Miop}

\begin{abstract}
This paper focuses on the strategies used by Mircea Eliade in his teenage years as a writer in order to construct an image of himself in his fictional text Romanul adolescentului miop. The author experimentally used literary devices to which we refer today as "self-insertion" or "author surrogate," resulting in a metanovel. Despite its flaws, the novel challenges the reader through an ingenious mixture of two narrative styles: the confessions of a diarist and the constructions of a novelist. Therefore, the reader is successively (and constantly) perceiving two different images of the author in Eliade's text: the glorious posture that he constructs for the public eye and the actual, troubled young author, simultaneously consumed by great ambitions and the dread that he will fail and his struggles are futile.
\end{abstract}

Keywords: Romanian Literature; Mircea Eliade; Metanovel; Self-insertion; Authenticity; Diary.

\section{IULIA RĂDAC}

Babeș-Bolyai University, Cluj-Napoca, Romania iuliaradac@gmail.com

DOI: 10.24193/cechinox.2017.32.26
$\mathrm{M}$ ircea Eliade, by now one of Romania's most prominent authors, was one of the main advocates of introducing authenticity into the country's interwar period novels. However, his works are characterized by an interesting paradox: while his theoretical articles strongly favor the exclusive use of a pure epic form, his novels feature a mixture of this pure epic and a very authentic writing style, right from the beginning. The text that this paper focuses on is situated on a fine line between an authentic diary and pure fiction. Romanul adolescentului miop is a novel about writing a nov$\mathrm{el}$, an original attempt of creating the first modern metanovel in Romanian literature.

Previous research about Mircea Eliade's work usually focused on the opinions he expressed in his essays and other theoretical articles. This paper tries to add a new perspective to the discussion by closely examining the image of the writer directly within the novel. So far, this perspective has been either ignored, taken for granted, or subjugated to the demonstration of other ideas.

Romanul adolescentului miop was written in 1925, when the author was 
approximately 18 years of age, and remained unpublished until 1989. It is one of Eliade's most elaborate teenage works and the mature author frequently referred to it on several later occasions. Mircea Handonca, one of Eliade's most important recent editors, considers the novel "the most valuable of the unpublished but finished works of Mircea Eliade's teenage years."1 According to literature critic Eugen Simion, the novel is important because in it the young Eliade tried for the first time:

1) to give a new image about the psychology of the teenage years, 2) to use in an autobiographical writing, obviously with the means of his age, what one later called the esthetic of authenticity and experience, and 3) to imagine a new way of constructing a novel in the shape of a diary of the author, which is, at the same time, also the narrator of the text. ${ }^{2}$

Although the project was ambitious, Simion believes that Eliade did not succeed in giving it an esthetic shape, but its formula to be similar to the one used by the more recent prose of Mircea Horia Simionescu and Costache Olăreanu. From his perspective, Eliade's novel represents another example of the distant origin of the metanovel, which therefore shouldn't be considered a discovery of postmodern prose. With the aforementioned three arguments, Eugen Simion manages to summarize the most important aspects of the novel. We will further discuss these ideas from a closer perspective and try to analyze if they construct the image of a new type of writer, very different from those who used the meta-feature before.
Firstly, through its theme, Eliade's novel is a critical reaction to Ionel Teodoreanu's Uliţa copilăriei (1923) and to the romanticism and the sentimentalism of the vision of teenagers in this and other similar works. From my perspective, the novelty of Eliade's text lies in the two facets of motivation for writing Romanul adolescentului miop which the narrator mentions within the text. An extrinsic motivation is visible in the way the narrator dreams about becoming a successful writer. Apparently superficial, this motivation can be considered an authentic one, closely resembling typical teenagers' struggles to win the respect of their peers and adults. In particular, the narrator of the book strives to avoid failing a re-examination in mathematics. An intrinsic motivation is represented in the wish to write a completely different novel than those he read. A novel that represents him. Actually, he does confess his inability to write a novel in the traditional meaning in the episode about Călătorie în jurul bibliotecii mele [Travelling around my Library]:

My Lord, but the books are stupid and cold. I wrote adorations about them in a thick notebook, which I liked to name: Travelling around my Library. I wanted to write, at first, a novel. I was the lover, the fiancé and the husband. The library was my mistress. One hundred pages later, I understood that I'll never be able to write a "novel." Instead of narrating meetings between lovers, I was writing prayers to the virginity of books. ${ }^{3}$

Like his narrator, the young Eliade quickly realizes that this is not the proper style for a novel and, in accordance with his 
narrator's principles, consequently abandons the literary passages from Romanul adolescentului miop. ${ }^{4}$ Distancing his work from classical narrative formulas, Eliade starts using a new mixture of styles: those of an authentic diary combined with pure fiction. He states that using only one of the two narrative styles would be inadequate, saying about an all-diary work: "I would be too preoccupied with intimate details and I won't be successful." ${ }^{\prime 5}$ For the fictive part, he stresses that it has to be based on authenticity:

I didn't find anything natural, experienced in my life that would convert my novel into a novel with a subject. My friends tell me that I will write a novel about pupils' behavior. A depraved, ignored world, not understood in literature. But I can't describe things. Without intention, I modify, exaggerate. And then, the novel must be published first and foremost to allow me to pass the 6 th grade. It has to be a mirror of my soul, without being a psychological novel; because I don't want it falsified by analysis. ${ }^{6}$

Instead of descriptive realism, the author prefers subjectivism, the only style capable of reflecting the inner feelings of the prose writer. Therefore, authenticity has a different meaning for Mircea Eliade, far from that given to it by other interwar authors like Anton Holban or Camil Petrescu. Eliade focuses on the experience, but rejects, at least at a theoretical level, the psychological analysis. Also, the fragment above is suggestive for the manner in which Eliade combines the two aforementioned motivations: gaining public reputation, but without compromising his own vision about the novel. Another short but exemplifying fragment is the one in which the teenager speaks about the exam that ends the tumultuous period: "In the novel, if I'll ever write it, I shall gather all the stupidities, all the absurdity of the high-school graduation exam. I shall prove with many examples that the lucky pass, the privileged, the dumb." ${ }^{\text {T }}$ Through confessions like this one, Romanul adolescentului miop positions itself critically against several positive novels about teenagers of the interwar period that offer a coherent image of their protagonists. Eliade, as he mentions in his diaries and recollections, believes that this coherent portrayal of people in their puberty must inadvertently be wrong. Eugen Simion believes that

especially ignoring this fake literature gives some literary value to these confessing pages. I got the impression that they say a lot about young Eliade's biography and also, they say something about a possible teenage character who wants to distinguish himself from common literary patterns. ${ }^{8}$

It is true that in this case the border between biography and fiction is fragile. Eugen Simion observes that many of the experiences noted in the novel correspond to real life events of Eliade's biography and that the novelist himself recalls, in his later Memories and diaries, some events which one can find in the novel. Simion appreciates the novel only in relation to the writer's biography and his mature works. Even if this would be the appropriate approach, the fact that Eliade later uses this narrative strategy in another novel, S,antier, which 
was warmly received by its reviewers, demonstrates that it was more than just a literary experiment. Though Eliade's aim to distance his writing from classical literary patterns remained mostly an intention with only limited actual results in his first novel, it still remains an indication of the writer's originality.

The characteristic struggle of the creative teenager is visible in the discrepancy between the posture of the writer - created in relation to his friends and classmates - and the fragile inner being, always confused and insecure. The latter is preeminent in the actual diary, which was later converted into the novel:

They asked me how much I wrote for the novel. I lied to them, telling them that I'm working on the second part. But don't I know that I'll never write Romanul adolescentului miop, for my memories and observations cannot be converted into a novel? They asked me to recount chapters from the novel. I recounted fragments of what I had written in the notebook. I told them that even this spontaneous and complete meeting - maybe the last of our career as pupils - will be reproduced in a chapter. ${ }^{9}$

In moments of solitude, being aware of the novelty of the type of prose that he's writing becomes a huge source of the fear that he will fail. Eliade's text is not a novel. Romanul adolescentului miop is not the type of novel that readers were used to, but due to its focus on authenticity it has the ability to show the real, unmodified life of teenagers. Literature comes closer to reality: "Dinu is secretively happy that he will have a friend with an adventurous life, who will write successful novels and whose company he can be proud of at private gatherings." ${ }^{10}$ Both teenagers perceive the profession of being a writer, especially a successful one, as a great accomplishment among their fellows. It is a yearning that balances their moods of enormous disbelief regarding various aspects of their lives, but mostly it compensates for the stagnation in daily school routine. Romanul adolescentului miop is not a novel with a subject in the classical sense; it rather emphasizes on the immediate experience, which may represent the "fuel" of the writing process. Thus, writing the novel is not only a pretext of ignoring the school situation, but it also justifies said situation:

What if I would repeat the year? Wouldn't this be the spark that lights the whole powder of my soul? Don't I need a deep pain, a change that will lead me directly to the greatest work of my life? I imagined myself sad, despised by friends, mocked by relatives and enemies, and I understood that this is the only way to write Romanul adolescentului miop, which will make me famous overnight, like Selma Lagerlöff, and rich, like Blasco Ibaňez."11

All these illusions of the writer's reputation represent just one of the two extremes between which the young writer oscillates. At the antipode of this bright perspective, one can find the loathing of the ephemeral and immediate fame, obtained through writing articles. The happiness of seeing his name printed temporarily replaces the great ambitions: 
Instead of walking alone and proud with all my thoughts and with the books written, I gave myself up little by little, with articles published in popular magazines, with pages in which one cannot find neither my soul, nor my thought, with lines written without enthusiasm and originality. ${ }^{12}$

From Mircea Handoca's commentaries from the 1989 edition's preface, one can find out that the narrator was referring to publishing some nonliterary articles. Real life leaves the young writer with a very bitter impression, further and further from the image of his ideal world: "I hardly conquered - like everyone else - a place in the second-rate magazines' columns, which were printing my articles with typos and an incomplete signature." ${ }^{13}$ Young Eliade has difficulties to stand the great distance between the imagined reputation and the actual lack of significance of his real and rather mediocre life. In his diary, he is especially revolting against a certain image of the writer, which he nonetheless slowly but surely adapts:

So much viciousness was brooding in my soul that I impatiently waited for the publication of a translation and I got upset for its postponement. I also started like all the others who call themselves "writers." Those who wear their hair cut at the nape and black lavaliere and a wide brimmed hat. Those who befriend the directors to get a novella published per month. Those who publish a poetry volume at a provincial print shop, a volume of novellas with a colorful cover, then become clerks in some office, get married and endure their whole life the burden of a weak wife and some uneducated children. ${ }^{14}$

In the fragment above one can observe the revolt against the appearance of the writer, against an image without substance, but also against accepting compromises in someone's vocation and personal life. Already in Eliade's first novel, a recurrent idea of his prose is visible: the incompatibility between the vocation of an artist and the family life of the common people. Thus, although his friends praise him for getting closer to normality, he is blaming himself: "I had my little glory, too. I had the mediocre content of an article published on the front page of the magazine, without typos and with my name under the title." ${ }^{15}$ These confessions express the most intimate contradictions and satisfactions of the narrator, unlike in objective prose. Eliade brings out the turmoil of his soul in the novel using the strategy of a diary and also because the main component of his artistic belief is authenticity. The writer is able to capture the teenager's psychology, to point out his contradictions, and even the paradoxes. The novel has the appearance of a diary from which the specific temporal indications are missing, but the chronology may be observed from the chapters' titles. In the chapter entitled "One year," the teenager notes: "One year had passed and I didn't write anything in this notebook. Why would I? Romanul adolescentului miop seems useless. I laughed many times with Dinu reminiscing about it and my plans. The glory of a precocious writer doesn't tempt me anymore." ${ }^{16}$ During the teenage years', ideas change quickly, some are abandoned, others come back proving 
their potency. Although the teenager declares that he abandoned his plan of writing the novel, the actual process of creating proves itself to be more than just a glorious dream, an inner longing. Even while Dinu and the narrator do not seem to take the novel seriously anymore, the diary that records all these changes of perspective actually becomes the novel. Eliade's sarcasm aims at the aspiration of being a writer and the associated public image, but he does not abandon the idea of creating a novel.

In a study about Romanian literature of the interwar period, Ovid S. Crohmălniceanu believes that Eliade's prose "is a direct continuation of his essays. The novels are, at least at the beginning, some ' $\mathrm{di}$ aries' meant to record, without any 'literary' inclination intellectual 'experiences',"17 in a manner inspired by Gide's work. Anyway, as Eugen Simion points out, when the teenager began to write his novel, André Gide's Les Faux-monnayeurs [The Counterfeiters] (1926), was not yet published, so we cannot speak about an influence, but about a particular understanding of the notion of "authenticity." ${ }^{18}$ Favoring authenticity, the novel begins with a confession with an ambiguous meaning: "Because I was alone, I actually decided to begin today with Romanul adolescentului miop. I don't need inspiration; I just have to write down my life, and I know my life, and it's been a while since I was thinking about the novel." ${ }^{19}$ On one hand, authenticity means for Mircea Eliade to transpose his blank life without any stylistic revision. On the other hand, trapping the author and the reader in the same metaphorical circle of the book might undermine the idea of this authenticity, throwing the novel in an area of conventions. The narrator declares that he cautiously ignores common tropes of literature but he still uses exactly those when talking about his teenage experiences in the novel. Moreover, he himself had secretly written classical literature before. The reader finds out about this from a random recollection: "During lunch, I remember the first secret notebook with a cover indicating: Novellas, $1^{\text {st }}$ volume." ${ }^{20}$ Therefore, when the teenager discovers Giovanni Papini's novel, reading it is a painful experience of self-discovery. Being exposed as a writer nullifies the joy of finding oneself in a fictional other: "Today, I read Giovanni Papini's Omul sfârșit [The Failure]. From now on, I'm also exhausted. My novel will never turn into pages and chapters. And I have to change myself. I have to, so that no one can tell that I imitated Giovanni Papini." ${ }^{21}$ As a writer, he is not only interested in being faithful to his soul and not only in subjectivity as a unique mode to be objective, as Camil Petrescu and Anton Holban believed, but Eliade is also interested in being original. Nonetheless, reading literature helps him discover his true self, so that at the end of the chapter he regains trust:

I'm not afraid of anyone. I'm ready to prove to everyone my gold and my jewels. Even to Giovanni Papini. And I'd like to hear that someone dares to blame me for plagiarism. And for my novel being a copy of $U n$ om sfârșit [The Failure]. I'd like to meet the one who will doubt my flesh and spirit. He will find me, shortsighted teenager, under the stack of my books from the attic. Come, envious and bickering. I'll greet him, I'll let him feel my thoughts' articulations, to turn my drawers upside down, to close old wounds. Maybe, until sunset, one of us will smile. ${ }^{22}$ 
“The narrator's diary is a 'mise en abyme' of a teenager's novel" 23 and consequently one can observe in it another oscillation of the main character, between two complementary activities: to write literature and to read literature, both registered in the same diary: "It's getting warmer and warmer. I didn't work at all on my novel. My papers and my notebooks are waiting for me in the drawer and I'm reading Anatole France and dreaming every night." ${ }^{24}$ The diary has also a healing function. Like in Anton Holban's novels, even if it does not disappear, once the suffering is written down it becomes bearable. The act of writing is not only a means of drawing the whole intertextual circle, and not only an instrument to organize the different notations, it also represents an aim, as it results from one of the final fragments of the novel: "I want to end the diary on this autumn day. I end it because I can't wait to begin right now with the novel. I sketched the first chapters. I'll write: 'Because I am alone, I actually decided to begin today with Romanul adolescentului miop'." 25 With this twist, Eliade comes full circle and the incipit of the novel is identical to that of the diary, reminding us of M. C. Escher's famous lithography Drawing Hands.

Being at the same time the author's diary and the narrator's diary, Romanul adolescentului miop is stylistically poor, as the convention of the genre requires. In his study, In căutarea autenticitătii, ${ }^{26}$ Dumitru Micu explains the mutation which characterizes the literature of the first half of 20th century, from the finished, perfect work to the work in progress. Perceived as a process, the new work of art is imperfect but, therefore, authentic. Subjective literature is more and more intensively rejecting the fictionalization and, instead, favors the aesthetics of authenticity. Thus, the untended phrase takes the place of beautiful style, reducing the differences between novel and diary, the latter considered the only genre capable to present authentic life. Mircea Eliade succeeds in approaching authenticity a unique way, turning it into a framework for a metanovel which describes the writing process of itself. Eliade's self-insertion into his text transformed biography into a literary device, obtaining a new type of subject, as Jerome Klinkowitz shows in Structuring the Void, ${ }^{27}$ by analyzing Kurt Vonnegut's America. Remaining unpublished for many decades, Eliade's experiment - although a boldly different concept for that period of Romanian literature did not have any echo. When Romanian critics finally started to discuss Eliade's early work, they focused almost exclusively on its shortcomings as an epic novel instead of its originality as an authentic one.

\section{BibliograPHY}

Crohmălniceanu, Ovid S. Literatura română între cele două războaie mondiale, vol. I, București, Editura pentru literatură, 1967

Eliade, Mircea. Romanul adolescentului miop, București, Editura Humanitas, 2004

Fânaru, Sabina. Eliade prin Eliade, București, Editura Univers, 2003

Handoca, Mircea. Mircea Eliade: Câteva ipostaze ale unei personalități proteice, București, Editura Minerva, 1992

Klinkowitz, Jerome. Structuring the Void. The Struggle for Subject in Contemporary American Fiction, Durham \& London, Duke University Press, 1992 
Micu, Dumitru. În căutarea autenticității, vol. I, București, Editura Minerva, 1992

Simion, Eugen. Mircea Eliade, spirit al amplitudinii, București, Editura Demiurg, 2001

\section{Notes}

1. Mircea Handoca, Mircea Eliade: Câterva ipostaze ale unei personalități proteice, București, Editura Minerva, 1992, p. 230.

2. Eugen Simion, Mircea Eliade, spirit al amplitudinii, București, Editura Demiurg, 2001, p. 17.

3. Mircea Eliade, Romanul adolescentului miop, București, Editura Humanitas, 2004 p. 75.

4. For the different variants of Romanului adolescentului miop see Mircea Handoca, "Primul roman," in Mircea Eliade, Mircea Eliade: Câteva ipostaze..., p. 230-248.

5. Mircea Eliade, op. cit., p. 15.

6. Ibid.

7. Ibid., p. 170.

8. Eugen Simion, op. cit., p. 19.

9. Mircea Eliade, op. cit., p. 154.

10. Ibid., p. 71.

11. Ibid.

12. Ibid., p. 106.

13. Ibid.

14. Ibid.

15. Ibid.

16. Ibid., p. 146.

17. Ovid S. Crohmălniceanu, Literatura română între cele două războaie mondiale, vol. I, București, Editura pentru literatură, 1967, p. 521.

18. Eugen Simion, op. cit., p. 20.

19. Mircea Eliade, op. cit., p. 7.

20. Ibid., p. 77.

21. Ibid., p. 142.

22. Ibid., p. 145.

23. Sabina Fânaru, Eliade prin Eliade, București, Editura Univers, 2003, p. 249.

24. Mircea Eliade, op. cit., p. 65.

25. Ibid., p. 173.

26. Dumitru Micu, În căutarea autenticității, vol. I, București, Editura Minerva, 1992.

27. Jerome Klinkowitz, Structuring the Void. The Struggle for Subject in Contemporary American Fiction, Durham \& London, Duke University Press, 1992, p. 29. 